\title{
Quantitative analysis of selenium species in sea food using solid phase extraction and HPLC-ICP/MS
}

\author{
Eunju Kim ${ }^{1}$, Minkyu Joo ${ }^{1}$, Hyosik Kwon ${ }^{2}$ and Yongnam Pak ${ }^{1, \star}$ \\ ${ }^{1}$ Department of Chemistry Education, Korea National University of Education, Cheongwon, Chungbuk 363-791, Korea \\ ${ }^{2}$ Department of Chemistry Education, Chungbuk National University of Education, Cheonju, Korea \\ (Received August 13, 2013; Revised September 2, 2013; Accepted September 2, 2013)
}

\section{해산물 시료에서 solid-phase extraction 및 HPLC-ICP/MS를 이용한 셀레늄 화학종의 정량분석}

\author{
김은주 ${ }^{1} \cdot$ 주민규 $^{1} \cdot$ 권효식 $^{2} \cdot$ 박용남 $^{1,}$ \\ ${ }^{1}$ 한국교원대학교 화학교육과, ${ }^{2}$ 충북대학교 화학교육학과 \\ (2013. 8. 13. 접수, 2013. 9. 2. 수정, 2013. 9. 2. 승인)
}

\begin{abstract}
Selenium exists in various forms of chemical species. The activity and bioavailability is strongly dependent on its chemical form and concentration. Consequently the information on each selenium species and its concentration must be exactly determined for the food we take in. In this study, selenium species in seafood were separated and quantified by RP (reversed phase) HPLC (high performance liquid chromatography) coupled with ICP-MS (inductively coupled plasma mass spectrometry) using post-column isotope dilution. ${ }^{79} \mathrm{Br}$, which interferes on ${ }^{80} \mathrm{Se}$, has mostly been removed by solid phase extraction and then mathematical correction has been applied for the more accurate correction. The experimental result for CRM (certified reference material) DOLT-4 agreed well with the certified value but each selenium species could not be compared. SeCys (selenocysteine) and SeMet (selenomethionine) were the major species detected in seafood such as belt fish, spanish mackerel, and squid that have been serving as Korean diet. The concentrations found in Korean sea food for SeCys and SeMet were in the range of $0-661.6 \mathrm{mg} / \mathrm{kg}$ and $137.3-462.7 \mathrm{mg} / \mathrm{kg}$, respectively.
\end{abstract}

요 약: 셀레늄은 다양한 화학종으로 존재하며 그 농도와 형태에 따라 활성도나 생물학적 이용도가 달라지므로 식품에 대한 셀레늄 화학종의 정확한 분리 및 정량이 필요하다. 본 연구에서는 역상 (RP; reversed phase) 고성능 액체 크로마토그래피 (HPLC; high performance liquid chromatography)와 유도결합 플라즈마 (ICP; inductively coupled plasma) 질량분석법 (MS; mass spectrometry)을 사용하여 해산물 시료 중 셀레늄 화학종을 분리 검출 한 뒤에 후 컬럼 동위원소희석법 (post column isotope dilution)으로 정확히 정량 하였다. 시료 중 ${ }^{80} \mathrm{Se}$ 의 간섭요인인 ${ }^{79} \mathrm{Br}$ 을 제거하기 위해 고체상 추출법을 사용하여 대부분 의 ${ }^{79} \mathrm{Br}$ 을 제거하였고 남아있는 ${ }^{79} \mathrm{Br}$ 은 수학적 보정식을 이용하여 보정해주었다. $\mathrm{CRM}$ (certified reference material) DOLT-4를 사용하여 셀레늄의 총량을 분석한 결과는 인증치와 잘 일치하였지만 각 화학종에

$\star$ Corresponding author

Phone : +82-(0)43-230-3732 Fax : +82-(0)43-232-7176

E-mail : pakyn@knue.ac.kr 
대한 정보는 비교할 수 없었다. 한국인 식탁에 오르는 대표적인 해산물 시료인 갈치, 삼치, 오징어, 등을 분석한 결과, 주된 셀레늄 화학종은 $\mathrm{SeCys}$ (selenocysteine)와 SeMet (selenomethionine)이었으며 각각은 0-661.6 mg/kg and $137.3-462.7 \mathrm{mg} / \mathrm{kg}$ 의 농도로 존재함 을 알 수 있었다.

Key words: selenium, HPLC-ICP-MS, Se species, sea food, solid phase extraction

\section{1. 서 론}

셀레늄은 극미량 미네랄로서 단백질과 결합하여 여러 항산화효소들을 만들어 라디칼들을 제어하거나 인체 의 면역체계에 작용하는 중요한 원소이다. ${ }^{1,2}$ 현재까지 인체에는 셀레늄을 포함하는 효소 및 단백질이 25 종류 이상이 밝혀져 있으며, 이 들은 항산화 작용에 의한 면역력 증가, 항바이러스 작용, 항암 효과, 심장병 예방 등의 효과가 있는 중요한 역할을 한다. ${ }^{4,5}$ 셀레늄이 부족할 경우, 케샨병이나 심장병 또는 prostate 암의 유발 같은 질병이 나타나며 6,7 인체의 건강유지에 필수 적이므로 “새로운 비타민"이라고 정의되고 있다. 동시에 셀레늄을 과잉으로 섭취하면 독성을 일으켜서 피부병 과 같은 셀레늄증 (selenosis)을 가져오게 된다. ${ }^{89}$

따라서 건강과 밀접한 셀레늄을 포함하는 식품에 대한 연구들이 유럽을 중심으로 많이 진행되어 왔으며 여러 나라에서는 식품에서 섭취되는 셀레늄의 량을 모니터링하고 있다. 중국이나 러시아 일부지역에서는 셀레늄 결핍증으로 인한 질병을 보이는 집단이 관찰된 바 있고 따라서 이를 기점으로 각 나라에서는 셀레늄 의 섭취량을 주의 깊게 모니터링하고 있으며 우리나라 에서도 식품에 대하여 조사한 바 있다. ${ }^{10}$ 셀레늄은 대개 식물을 통하여 섭취하게 되나, 고기 및 해산물에도 풍부하게 함유되어있다. 현재 각 국의 셀레늄 섭취량 한도는 나라마다 다르나 미국의 경우에는 성인일 경우 $55 \mu \mathrm{g} / \mathrm{kg}$, 유럽은 $60 \mu \mathrm{g} / \mathrm{kg}$ 으로 권고하고 있고 우리나라는 $50 \mu \mathrm{g} / \mathrm{kg}$ 이며 하루 최대 섭취량은 400 $\mu \mathrm{g} / \mathrm{kg}$ 로 제한되고 있다.

현재까지 셀레늄의 정량분석은 주로 농산물과 동식 물에 많이 집중되어 있으며 해양생물 또는 물고기에 대한 연구는 상대적으로 적다. 일본의 경우, 해산물에 의한 셀레늄의 섭취가 전체 음식중의 $60 \%$ 되는 것으로 보고되고 있다. ${ }^{11}$ 우리나라 또한 생선의 섭취량이 매우 높으며 따라서 해산물에 대한 셀레늄의 량을 조사하는 것은 매우 의미가 크다. 초기의 연구에서는 생선이나 해양생물이 더 많은 셀레늄을 함유하고 있지만 생화학적 활용도는 곡류에 비해서 떨어지는
것으로 보고하였는데 ${ }^{12,13}$ 그 이유는 해양생물에 포함된 높은 농도의 수은이나 중금속이 셀렌의 섭취를 방해 하거나, 섭취가 어려운 형태로 많이 존재하기 때문으로 보고되었다. 하지만 좀 더 최근의 연구 ${ }^{14,15}$ 에 의하면 참치나 생선이 곡류나 이스트에 비하여 더 높은 이용 도를 보이는 것으로 보고되고 있다. 따라서 해산물에 대한 연구는 의미가 크며 특히 셀레늄의 경우, 시료에 대한 화학종의 정보가 필요하며 이 를 바탕으로 정확 한 생화학적 이용도를 판단할 수 있는 근거가 될 것이다.

결국 셀레늄의 전체량에 대한 정보를 알기보다 더 중요한 것은 어떤 형태로 존재하느냐 하는 것이다. 그 화학종 형태에 따라 또는 어떤 화합물이냐에 따라 그 화학적 특성과 생화학적 이용도 및 인체 내에서의 역할이 매우 달라지기 때문이다. 비소의 경우에는 비활 성인 arsenobetain으로 많이 존재하면 비소의 총 량은 많지만 생화학적 활성도는 높지 않게 된다. 대개 음식 물에서는 유기형태의 화합물인 SeMet 또는 SeCys 및 그 유도체들로 존재한다. 비록 무기셀레늄들(Se IV 또는 $\mathrm{Se} \mathrm{VI}$ )이 비료 등으로는 많이 사용되지만 실제의 음식물에서는 많이 발견되지 않는다. SeMet의 경우는 인체에 흡수되기 쉬우며 생화학적 이용도가 우수한 것으로 알려져 있다. 따라서 유럽에서는 무기 셀레늄 용액에서 배양한 이스트를 사용하여 유기 셀레늄으로 전환시킨 뒤 생화학적 이용도를 높여서 동물의 사료에 넣어서 사용하고 있다.

식품에서의 셀레늄 화학종에 관한 기존의 연구를 살펴보면 Vanesa 등 ${ }^{16}$ 은 SEC (size exclusion chromatography)-HPLC-ICP/MS, RP-HPLC-ICP/MS, AE (anion Exchange)-HPLC-ICP/MS등의 방법을 이용하여 버섯 시료 중의 셀레늄 화학종을 분리하고 정량 하였다. Celine 등 ${ }^{17}$ 은 식물식품에 비해 동물 식품이 셀레늄을 더 많은 양, 특히 생선과 갑각류에 셀레늄이 가장 많이 존재 하고 있다고 보고하였고 Moreno 등 ${ }^{18}$ 의 연구에 서는 참치, 크릴새우, 굴, 홍합 중 셀레늄 화학종을 분석하였는데 그 결과 모든 시료에서 SeMet이 검출되 었으며, 크릴새우 중에는 무기 셀레늄인 Selenite도 
검출되었다. Reyes, ${ }^{19}$ Quijano ${ }^{20}$ 는 참치, 송어, 굴, 홍합 등의 시료 중 SeMet이 주된 셀레늄 화학종으로 존재 하며, 적은 양이지만 selenomethyl cystein (MeSeCys) 또는 trimethylselenonium $\left(\mathrm{TMSe}^{+}\right.$)이나 알려지지 않은 셀레늄 화학종도 존재함을 밝혔다.

국내에서는 아직까지 셀레늄의 총량 분석에 관한 연구만 있었는데 $\mathrm{Choi}^{10}$ 의 연구에서는 생선, 갑각류, 버섯, 곡류, 과일, 해조류 등의 한국 식단의 대표적 음식들 중 셀레늄 총량을 정량하였으며, $\mathrm{Jang}^{21}$ 의 최근 연구에서는 마늘, 돼지고기, 고등어 등의 시료 중에서 셀레늄 화학종을 추출 및 정량 하였다. 본 연구에서는 국내에서 식탁에 친숙하게 자주 오르는 대표적인 생선들을 중심으로 셀레늄의 여러 화학종들을 조사하 고 그 농도를 정확히 분석하고자 하였다.

수 $\mu \mathrm{g} / \mathrm{kg}$ 수준인 미량의 셀레늄의 화학종들을 정확히 분석하기 위하여서는 첨단의 기기와 주의 깊은 정량 분석법이 요구된다. 먼저 HPLC를 사용하여 여러 셀레 늄 화학종들을 분리시킨 다음 ICP/MS로 분석하는데 HPLC-ICP/MS는 현재까지 알려진 여러 기술 중에 가장 강력한 화학종 연구의 기술이라고 할 수 있다.

셀레늄을 ICP/MS로 분석할 때에 $\left[{ }^{74} \mathrm{Cl}_{2}\right]^{+},\left[{ }^{40} \mathrm{Ar}^{37} \mathrm{Cl}\right]^{+}$ 및 $\left[{ }^{80} \mathrm{Ar}_{2}\right]^{+}$와 같은 분자들은 셀레늄의 $m / z 74,77,80$ 에 대하여 동중간섭을 가져올 수 있다. 하지만 최근의 충돌/반응셀의 기술의 발전으로 간섭분자들을 제거할 수 있게 되었는데 본 연구에서도 팔중극자 반응셀 (ORC; octapole reaction cell)이 장착된 $\mathrm{ICP} / \mathrm{MS}$ 를 사용하여 동중간섭들을 배제할 수 있었다. 또한 $\mathrm{HPLC}$ 는 여러 화합물들을 일차적으로 분리하므로 매트릭스가 상대적으로 간단하여지고 여러 간섭요인 들이 줄어들지만 그럼에도 불구하고 시료에 포함된 여러 이온들은 여전히 일부 피크와 겹칠 수 있다. 예를 들어, $\mathrm{Br}$ 이 매트릭스에 포함된 경우, $\mathrm{ORC}$ 에서 사용하는 수소기체와 반응하여 $\left[{ }^{79} \mathrm{BrH}\right]^{+},\left[{ }^{81} \mathrm{BrH}\right]^{+}$를 만들어 ${ }^{80} \mathrm{Se}$ 과 ${ }^{82} \mathrm{Se}$ 에 간섭을 가져올 수 있다. 총량분석의 경우에는 간섭이 없는 ${ }^{77} \mathrm{Se}$ 를 사용하면 되지만 동위원소 희석법 (ID; isotope dilution)을 사용할 때에는 여러 동위원소 들을 사용하게 되고(예; $\left.{ }^{80} \mathrm{Se}\right)$ 이 들에 대한 간섭의 제거가 필요하게 된다. 일차적으로는 매트릭스에 의한 동중간섭이 적은 동위원소를 선택하여 사용하게 되지 만, 필요한 경우에는 $\mathrm{ORC}$ 에서의 반응기체를 바꾸어 간섭이온의 생성을 억제 22 하거나 아예 매트릭스를 제 거하여 분석하여야 한다. 본 연구에서는 음이온 교환 고체상추출(SPE; solid phase extraction)을 이용하여 매트릭스를 제거한 뒤에 셀레늄의 정확한 분석을
연구하였다.

분석 기법 중에 가장 정확한 방법은 동위원소 희석 법이지만 분자나 화합물의 경우에는 동위원소로 표지 된 표준물을 구하는 것이 필요하다. 하지만 모든 화합 물에 대하여 동위원소로 표지하는 것은 매우 어려우 므로 동위원소 표준물을 구할 수 없다면 species unspecific ID 법 ${ }^{23}$ 을 적용 하여야 한다. HPLC의 경우 에 컬럼의 뒤에 표준물 동위원소를 넣어주므로 후 컬럼 (post column) ID법이라고도 불리며 이 방법은 비록 컬럼 이 전에서 발생되는 여러 오차에 대하여서는 보정이 불가능하지만 컬럼 이 후에 일어나는 오차에 대하여서는 보정이 가능한 정확한 방법이다.

본 연구에서는 $\mathrm{SPE}$ 를 사용하여 셀레늄 화학종에 간섭하는 이온들을 제거한 뒤에 HPLC-ICP/MS로 분석하였고 이때에 후 컬럼 ID법을 이용하여 여러 셀레늄의 화학종들에 대하여 정확한 량을 결정할 수 있었는데 국내에서는 처음으로 우리나라에서 식탁에 친숙하게 오르는 해산물의 셀레늄 화학종에 대한 정량 분석을 하였다.

\section{2. 실 험}

\section{1. 기기}

ICP/MS (7500ce, Agilent, Tokyo, Japan)는 ORC이 장착되어 있으며 시료 도입에는 concentric 분무기를 사용하였다. HPLC는 L-6200A Intelligent (Hitachi, Tokyo, Japan)를 사용하였다. 셀레늄 화학종을 분리하기 위한 컬럼은 Kromasil $300-10 \mathrm{C}_{8}(250 \times 4.6 \mathrm{~mm})$ 을 사용하 였다.

\section{2. 시약 및 시료}

실험에 사용한 모든 용기와 기구는 진한 질산으로 세척 후 탈 이온수로 씻고 건조하여 사용하였다. 용기 세척과 시료 제조에 사용한 질산은 동우화인켐에서 구입한 반도체급 시약을 사용하였다. 셀레늄 표준 용액은 NIST SRM 3179 (Se standard stock solution $10.11 \pm 0.02 \mathrm{mg} / \mathrm{g}$ )를 $2 \% \mathrm{HNO}_{3}$ 에 묽혀 사용하였다. 셀레늄 화학종 표준용액은 Sigma-Aldrich (Saint Louis, $\mathrm{MO}, \mathrm{USA}$ )에서 구입한 sodium selenite (Se IV, 99\%)와 sodium selenate (Se VI, 99.999\%), DL-SeMet, L-SeCys, $\mathrm{MeSeCys}(95 \%)$ 를 탈 이온수에 묽혀 사용하였다. 시료 중 셀레늄을 추출하기 위해 사용한 효소는 protease XIV (from streptomyces griseus type)와 lipase (from porcine pancreas type II)는 Sigma-Aldrich에서 구입하 
여 사용하였다. 이온쌍 시약과 용매는 NFPA (nonafluoropentanoic acid, Fluka, Buchs, Switzerland)와 methanol ( $\geq 99.9 \%$, Sigma-Aldrich)을 사용하였고 표준 인증물질인 CRM DOLT-4 (dogfish liver)는 NRCC (National Research Council of Canada, Ontario, Canada) 에서 구입하였다. 이동상은 메탄올 $5 \%$ 와 $\mathrm{NFPA}$ 를 $0.05 \%$ 를 혼합한 후 $\mathrm{pH} 2.5$ 로 맞추었다.

\section{3. 실험과정}

$\mathrm{ICP} / \mathrm{MS}$ 와 $\mathrm{HPLC}$ 를 연결하는 경우 다량의 유기 용 매 주입으로 발생하는 탄소 흡착에 의해 sampler cone 이 막히는 등의 문제가 생길 수 있다. 따라서 makeup gas로 $\mathrm{Ar} / \mathrm{O}_{2}$ 혼합 기체 $\left(\mathrm{Ar} 80 \%, \mathrm{O}_{2} 20 \%\right.$ )를 사용하여 탄소를 산화시켰다. 시료 에 존재하는 셀레늄 화학종 을 분리하기 위한 최적의 조건을 구하기 위하여 먼저 5 개의 셀레늄 화학종 표준시료를 선행연구 ${ }^{21}$ 에 따라 분리하고 같은 조건으로 해산물 시료 중의 셀레늄 화 학종을 분리하였다. 이 후, 각 화학종의 확인을 위해 시료에 셀레늄 화학종 표준시료를 첨가하여 재점검하 였다. 셀레늄 화학종을 검출하기 위한 ICP/MS의 조건 과 분리를 위한 $\mathrm{HPLC}$ 의 최적 조건은 Table 1에 나타 내었다.

시료에서 셀레늄화학종을 효율적으로 추출하기 위 하여 마이크로파를 이용한 효소추출법을 사용하였다. 먼저 동결 건조시켜 분쇄한 시료를 Teflon 용기에 200 $\mathrm{mg}$ 넣고, protease XIV $20 \mathrm{mg}$, lipase $5 \mathrm{mg}, 50 \mathrm{mM}$ phosphate buffer $(\mathrm{pH} 7.5)$ 를 $10 \mathrm{~mL}$ 가한 후 마이크로 파를 이용하여 $37{ }^{\circ} \mathrm{C}$ 에서 30 분간 분해시킨 뒤에 추출하였다. 그 다음 10 분간 원심분리 (4000 rpm)하여 상등액을 증류수로 묽힌 후 $0.45 \mu \mathrm{m}$ PVDF syringe filter (Millipore, Bedford, USA)를 이용해 여과시켜 주 었다. 시료는 분석 전까지 $4{ }^{\circ} \mathrm{C}$ 에 보관하였고 분석전

Table 1. ICP/MS and HPLC operation conditions used in the experiment

\begin{tabular}{ll}
\hline \hline \multicolumn{1}{c}{ ICP/MS Condition } & \\
\hline RF power & $1500 \mathrm{~W}$ \\
Carrier gas & $0.90 \mathrm{~mL} / \mathrm{min}$ \\
Makeup gas $\left(\mathrm{Ar}+\mathrm{O}_{2}\right)$ & $0.12 \mathrm{~mL} / \mathrm{min}$ \\
Reaction gas & $\mathrm{H}_{2}, 4.0 \mathrm{~mL} / \mathrm{min}$ \\
\hline HPLC condition & \\
Column & Kromasil $\mathrm{C}_{8,}, 250 \times 4.6 \mathrm{~mm}$ \\
Mobile phase & $5 \%$ methanol, pH 2.5 \\
Ion paring reagent & $0.05 \% \mathrm{NFVA}$ \\
Flow rate & $1.0 \mathrm{~mL} / \mathrm{min}$ \\
\hline
\end{tabular}

에 SPE를 행하였다.

셀레늄 화학종의 정확한 정량을 위해 시료 중 간섭 이온들을 제거할 필요성이 있으므로 본 연구에서는 SPE cartridge (Bond elut-SAX, $500 \mathrm{mg}, 3 \mathrm{~mL}$, Agilent, Lake forest, USA)를 이용한 고체상 추출법으로 시료 중 $\mathrm{Br}$ 을 제거해주었다. 과정은 먼저 메탄올과 증류수 를 각 $2 \mathrm{~mL}$ 사용하여 씻어 준 뒤 시료를 $2 \mathrm{~mL}$ loading 시키고 증류수 $2 \mathrm{~mL}$ 를 사용하여 추출해 내었다.

후 컬럼 동위원소 희석법은 ${ }^{78} \mathrm{Se}$ 를 표준용액으로 하여 연속적으로 흘러 넣어 주었다. 이 때 얻어진 크로마토그램을 바탕보정한 뒤, mass bias 보정과 검출기에 대한 dead time correction을 행한 뒤에 얻어 진 신호를 사용하여 mass flow 형태로 바꾸고, 수학식을 사용하여 각 신호에 대한 질량값을 구한다. 얻어진 질량값들을 피이크의 전체 구간에 대하여 적분하면 총량을 얻을 수 있게 된다.

\section{3. 결과 및 논의}

삼치 시료를 준비한 후 고체상 추출을 거치지 않은 경우에서 RP HPLC-ICP/MS를 이용하여 분석한 결과 (Fig. 1(a)) 신호가 가장 큰 $\mathrm{m} / \mathrm{z} 80$ 번(굵은 점선)에서 2.7 분과 3.2 분에서 두 개의 피이크를이 검출되었다. 그러나 셀레늄의 다른 동위원소인 $\mathrm{m} / \mathrm{z} 78$ (실선)을 조사 해 보면 두 번째 피이크만 나타나므로 첫 번째의 피이크는 셀레늄 화학종이 아님을 알 수 있다. $\mathrm{Br}$ 에 대한 $m / z$ 79(점선)를 조사해 보면 첫 번째 피이크의 위치에서 겹치는 것을 보아 $m / z$ 80에서 나타났던 첫 번째 피이크는 매트릭스의 ${ }^{79} \mathrm{Br}$ 과 $\mathrm{ORC}$ 에서의 수소기 체의 반응의 결과로 생긴 $\left[{ }^{79} \mathrm{BrH}\right]^{+}$임을 알 수 있다. $\mathrm{SPE}$ 를 사용하여 시료에서 $\mathrm{Br}$ 을 제거한 뒤 얻어진 결 과를 Fig. 1(b)에서 보여주었다. 이 때 두 번째 피이크 만이 나타남을 볼 수 있으며 SPE를 사용하여 $\mathrm{Br}$ 을 제거하는 것이 더 정확한 분석에 도움을 주는 것을 알 수 있다.

게살시료에 대하여 고체상 추출 전후의 ${ }^{79} \mathrm{Br}$ 의 신호 세기를 비교한 결과를 Fig. 2에 나타내었는데 현재 $\mathrm{SPE}$ 를 사용하였을 때에 시료 중 존재하는 ${ }^{79} \mathrm{Br}$ 이 어 느 정도 제거되는 지를 보여준다. 대부분의 $\mathrm{Br}$ 은 제거 되는 것으로 보이며 현재 $\mathrm{Br}$ 의 제거 효율은 약 $95 \%$ 이었다. 하지만 $\mathrm{Br}$ 이 일부 남아 있을 수 있으며 남아 있는 $\mathrm{Br}$ 이 $\left[{ }^{79} \mathrm{BrH}\right]^{+}$를 생성하는 것에 대하여서는 수학 적 보정을 통하여 수정하였다.

게살시료에 대하여 SPE를 행하기 전과 후, 그리고 


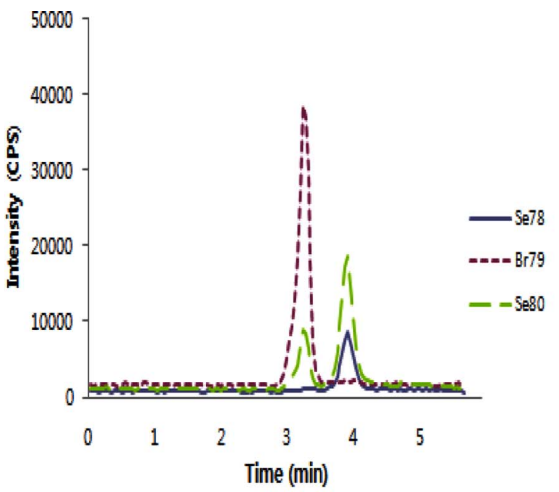

(a)

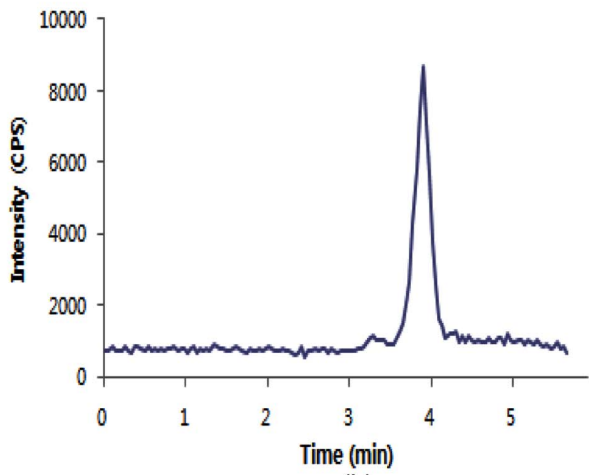

(b)

Fig. 1. Interference of $\mathrm{Br}$ on ${ }^{80} \mathrm{Se}$ for spanish mackerel in RP HPLC-ICPMS when SPE is not applied (Fig. 1(a)) and SPE is applied (Fig. 1(b)).

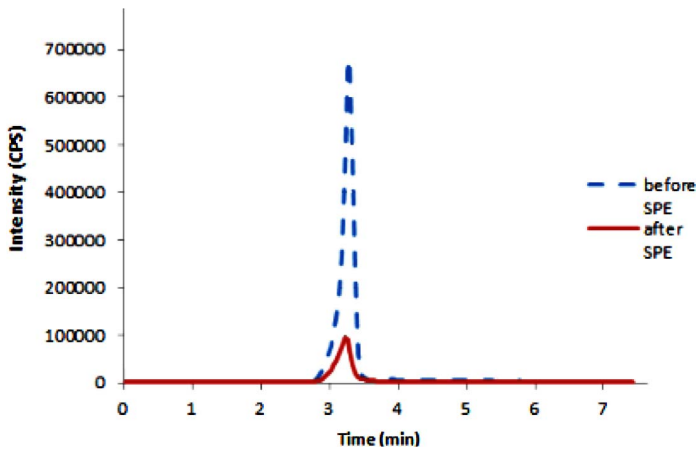

Fig. 2. Comparison of ${ }^{79} \mathrm{Br}$ signal in crab meat when SPE is not not applied (--- line) and SPE is applied (- line).

Table 2. Correction of $\mathrm{Br}$ interference for the measurement of SeCys with SPE and mathematical correction methods applied for crab meat

\begin{tabular}{cccc}
\hline \hline $\begin{array}{c}\text { Crab meat } \\
\text { (SeCys) }\end{array}$ & Before SPE & After SPE & $\begin{array}{c}\text { Aftermathematical } \\
\text { correction }\end{array}$ \\
\cline { 2 - 4 } & $190.83 \pm 1.31$ & $109.82 \pm 9.59$ & $73.08 \pm 4.27$ \\
\hline
\end{tabular}

average \pm standard deviation $(\mathrm{n}=3)$, unit : $\mu \mathrm{g} / \mathrm{kg}$

수학적 보정을 하기 전과 후의 결과 값을 비교하여 나타내었다(Table 2). $\mathrm{Br}$ 은 $\mathrm{SeCys}$ 에 대하여 머무름 시 간이 겹쳐 영향을 주지만 SeMet이나 다른 피이크들은 별로 간섭을 받지 않으므로 $\mathrm{SeCys}$ 만 나타내었다. 먼 저 $\mathrm{SPE}$ 를 행하기 전과 후를 비교하여 보면 $\mathrm{SeCys}$ 의 량은 $190.83 \mu \mathrm{g} / \mathrm{kg}$ 과 $109.82 \mu \mathrm{g} / \mathrm{kg}$ 으로 매우 큰 차이 를 보임을 알 수 있다. $\mathrm{Br}$ 이 $\mathrm{BrH}^{+}$를 형성하여 오차를 가져오게 되는데 이전 연구 ${ }^{24}$ 에 의하면 ${ }^{79} \mathrm{Br}$ 은 현재의 조건에서 $20 \%$ 이상이 $\mathrm{BrH}^{+}$가 되어 ${ }^{80} \mathrm{Se}$ 에 영향을 준
Table 3. Analysis of Se for CRM DOLT-4 dogfish

\begin{tabular}{cccc}
\hline \hline & Total Se & \multicolumn{2}{c}{ HPLC-ICP/MS } \\
\hline exp. value & $8.2 \pm 0.85$ & SeCys & $1.58 \pm 0.28$ \\
& SeMet & $1.68 \pm 0.33$ \\
\hline ref. value & $8.3 \pm 1.3$ & SeCys + SeMet & $3.26 \pm 0.43$ \\
\hline average \pm standard deviation $(\mathrm{n}=3)$, unit $: \mathrm{mg} / \mathrm{kg}$
\end{tabular}

다. 본 연구의 경우, 게살시료에 대하여 수학적 보정 을 하지 않았을 때에 약 $30 \%$ 이상의 오차를 가져다 주고 있다. 따라서 $\mathrm{SeCys}$ 화학종을 연구하려면 매트릭 스를 제거하거나 보정하는 것이 필수적이며 비록 $\mathrm{Br}$ 을 많이 제거했다 할지라도 SPE 이 후에 남아있는 $\mathrm{Br}$ 은 여전히 간섭을 하게 되어 수학적 보정을 통하여 오차를 줄여야 할 것이다.

실험방법의 정확성을 검증하기 위하여 표준시료를 사용하여야 하나, 현재까지 셀레늄의 여러 화학종에 대한 표준시료는 존재하지 않는다. 우선 셀레늄 총량 에 대한 분석으로 표준물 CRM DOLT-4 dogfish 간 (liver)을 사용하였다, 실험에 대한 결과를 비교해 보면 (Table 3) 본 연구결과와 인증값이 좋은 일치도를 보 여주고 있다. 그 다음 화학종 연구로서 DOLT-4 표준 시료를 본 실험방법에 따라 추출한 다음 조사해 보았 다. $\mathrm{Se}$ 화학종의 정량적 연구는 각 화학종에 대한 인 증값이 없으므로 직접 비교할 수 없었으며 본 연구결 과에 의하면 $\mathrm{SeCys}$ 와 $\mathrm{SeMet}$ 이 각각 $1.58 \mathrm{mg} / \mathrm{kg}$ 과 $1.68 \mathrm{mg} / \mathrm{kg}$ 존재함을 알아내었다. 이 둘을 더하면 $3.26 \mathrm{mg} / \mathrm{kg}$ 으로 전체량인 $8.3 \mathrm{mg} / \mathrm{kg}$ 의 약 $40 \%$ 수준 에 머무르고 있는데 그 이유는 이 두 화학종 외에 다 른 무기셀레늄등의 다른 화학종으로 존재할 수 있기 


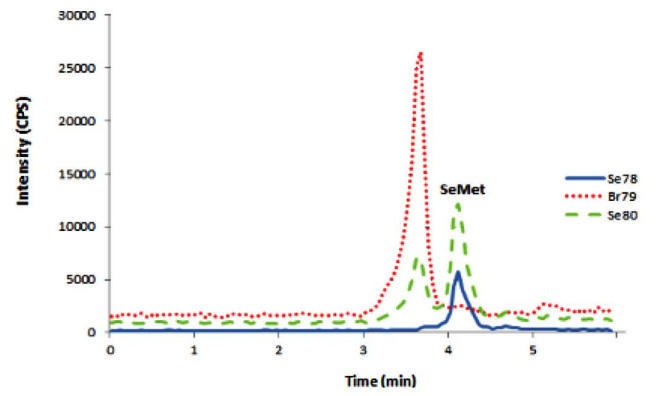

(a)

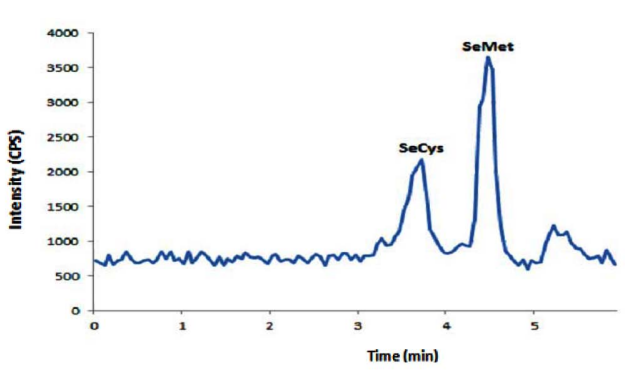

(b)

Fig. 3. (a) Separation of selenium species in whale meat by RP HPLC-ICP/MS wihout SPE, (b) Separation of selenium species in whale meat by RP HPLC-ICP/MS with SPE.

때문이다. 또 다른 이유는 추출이 $100 \%$ 되지 않을 수 있기 때문인데 특히 dog fish의 간에서 셀레늄 화학종 들을 identity를 유지한 채로 모두 추출해 내는 것은 매우 어려운 것으로 알려져 있다. ${ }^{25}$

고래 고기에 대한 셀레늄 화학종의 연구결과를 Fig. 3 에 나타내었다. 역시 $m / z 80$ 에서는 두 개의 피이크가 나타나지만 $m / z$ 78에서는 SeMet 한 개만 관찰된다. 하지만 $\mathrm{SPE}$ 를 사용하여 매트릭스를 제거한 뒤에 결과 를 살펴보면 (Fig. 3(b)) SeCys와 SeMet 두 개의 피이 크가 관찰됨을 알 수 있다. 현재로서는 $\mathrm{SeCys}$ 피이크 가 새로이 나타나는 이유가 $\mathrm{SPE}$ 를 이용한 추출 과정 에서 불안정한 $\mathrm{SeCys}$ 가 환원되어 나타나는 것인지 불분명하다. $\mathrm{SeCys}$ 의 불안정성은 잘 알려져 있으며 다른 연구에서도 관찰된 바 있다. ${ }^{26} \mathrm{SeCys}$ 는 불안정하 여 쉽게 산화되거나 dimer형태로 변할 수 있으므로 추출과정을 좀 더 주의 깊게 사용하여야 할 필요가 있다. 따라서 SPE를 사용하는 과정에서의 시료의 변 질을 줄이기 위하여 $\mathrm{Br}$ 의 농도가 높지 않으면 단순 수학적 보정을 통하여 간섭을 보정하였고 $\mathrm{Br}$ 의 농도 가 높은 경우에만 $\mathrm{SPE}$ 를 사용하여 제거하였다.

다음에는 해산물 시료에 대한 셀레늄 화학종이 분 리된 것을 대표적인 경우 몇 가지를 나타내었다. 대구

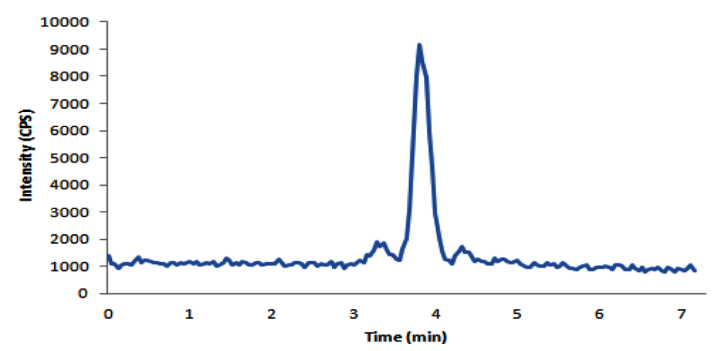

Fig. 4. Chromatogram for sole sample, which shows SeMet is the major selenium species.

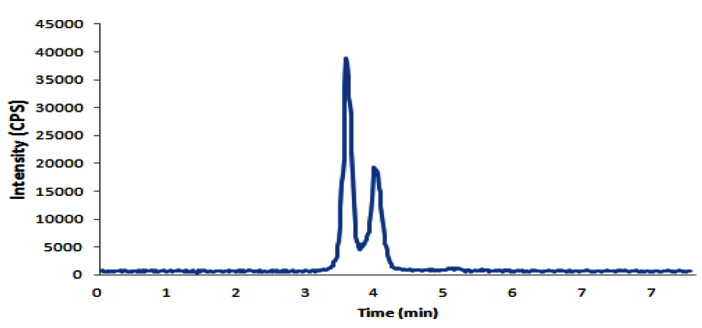

Fig. 5. Chromatogram for cod sample, which shows both SeCys and SeMet are the major selenium species.

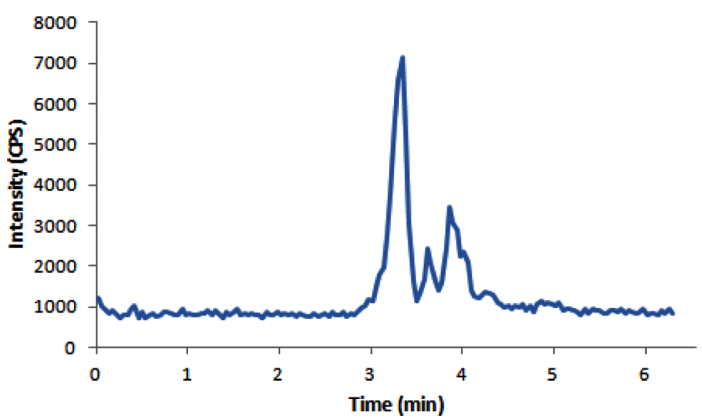

Fig. 6. Chromatogram for anchovy sample, which shows mostly SeCys, SeMet and minor MeSeCys (3.6 min) selenium species.

(Fig. 4)같은 경우는 $\mathrm{SeCys}$ 와 SeMet이 함께 존재하는 것으로 나타나며 가자미 (Fig. 5) 같은 경우는 $\mathrm{SeCys}$ 만 존재한다. 또한 멸치 (Fig. 6)는 SeCys와 SeMet 이 외에 $\mathrm{MeSeCys}$ 와 같은 다른 화학종들을 보이기도 한 다. 멸치는 우리 한국인의 식단에서국수의 국물용등으 로 매우 많이 소비되는 주요 셀레늄 섭취원인 해산물 이다. 이와 같이 해산물은 다양한 셀레늄 화학종들을 풍부하게 포함하고 있음을 알 수 있다.

한국인들이 즐겨 찾는 해산물 식품에 대한 셀레늄 화학종에 대한 분석 결과를 Table 4에 나타내었다. 
Table 4. Selenium species in representative Korean fish determined by post column isotope dilution RP HPLC-ICP/MS

\begin{tabular}{|c|c|c|c|c|}
\hline & $\begin{array}{c}\text { Se } \\
\text { species }\end{array}$ & $\begin{array}{l}\text { Conc. } \\
(\mu \mathrm{g} / \mathrm{kg})\end{array}$ & $\begin{array}{c}\text { Total } \\
(\mathrm{mg} / \mathrm{kg})\end{array}$ & $\begin{array}{c}\text { Ref. } \\
(\mathrm{mg} / \mathrm{kg})\end{array}$ \\
\hline \multirow{2}{*}{ Cod } & SeCys & $549.9 \pm 12.8$ & \multirow{2}{*}{1.013} & \multirow{2}{*}{$0.360^{\mathrm{a}}$} \\
\hline & SeMet & $462.7 \pm 16.6$ & & \\
\hline \multirow{2}{*}{ Belt fish } & SeCys & $661.6 \pm 15.5$ & \multirow{2}{*}{0.974} & $0.433^{b}$ \\
\hline & SeMet & $312.8 \pm 13.5$ & & $0.301^{\mathrm{a}}$ \\
\hline \multirow{3}{*}{ Anchovy } & SeCys & $630.0 \pm 8.1$ & \multirow{3}{*}{0.775} & \multirow{3}{*}{$\begin{array}{l}0.805^{\mathrm{b}} \\
0.753^{\mathrm{a}}\end{array}$} \\
\hline & MeSeCys & $35.5 \pm 7.3$ & & \\
\hline & SeMet & $144.8 \pm 9.4$ & & \\
\hline \multirow{2}{*}{ Squid } & SeCys & $339.4 \pm 28.4$ & \multirow{2}{*}{0.587} & $0.317^{\mathrm{b}}$ \\
\hline & SeMet & $247.6 \pm 6.5$ & & $0.448^{\mathrm{a}}$ \\
\hline \multirow{2}{*}{ Sole } & SeCys & - & \multirow{2}{*}{0.379} & \\
\hline & SeMet & $378.7 \pm 2.8$ & & \\
\hline \multirow{2}{*}{$\begin{array}{l}\text { Spanish } \\
\text { mackerel }\end{array}$} & SeCys & - & \multirow{2}{*}{0.305} & \\
\hline & SeMet & $305.5 \pm 13.4$ & & \\
\hline \multirow{2}{*}{ Monk fish } & SeCys & $579.2 \pm 1.7$ & \multirow{2}{*}{0.986} & \\
\hline & SeMet & $407.0 \pm 10.6$ & & \\
\hline \multirow{2}{*}{ Herring } & SeCys & $439.7 \pm 60.5$ & \multirow{2}{*}{0.577} & \\
\hline & SeMet & $137.3 \pm 23.7$ & & \\
\hline
\end{tabular}

${ }^{a}$ ref. 10

${ }^{b}$ ref. 27

이때 후 컬럼 동위원소 희석법을 적용하였는데 이는 각 동위원소 표준물이 없기 때문에 현재까지는 이 방 법이 가장 정확한 방법으로 알려져 있다. 대구나 아귀 는 비교적 높은 값을 보여주고 있다. 본 연구에서 얻 은 여러 해산물들에 대한 셀레늄의 총량을 다른 연구 들의 결과 ${ }^{10,27}$ 와 비교해 보면 비슷한 값을 보이고 있 다. 물론 각 시료는 잡힌 지역과 날짜에 따라서 다르 며 각 개체에 따라서도 다를 것이다. 무엇보다 시료 전체를 사용하였는지 아니면 부위별로 조사하였는지 에 따라서도 달라진다. 생선의 경우, 내장이 상대적으 로 높은 농도를 보이지만 본 연구에서는 육질만 조사 하였는데 이에 따라 타 연구의 보고된 값도 육질만 비교하였다.

\section{4. 결 론}

본 연구를 통하여 한국인의 식탁에 자주 오르는 해 산물에 대한 셀레늄 화학종들의 종류와 농도를 정확 하게 구할 수 있었다. 마이크로파 효소추출법을 이용 하여 효율적으로 추출한 뒤 RP HPLC-ICP/MS를 이
용하여 해산물 시료에서 셀레늄 화학종을 분리하고 후 컬럼 동위원소 희석법을 적용하여 $\mu \mathrm{g} / \mathrm{kg}$ 수준의 미량 셀레늄 화학종을 정량적으로 분석하였다. 대부분 의 해산물 시료에서는 $\mathrm{SeCys}$ 와 SeMet이 주로 검출되 었다. $\mathrm{SPE}$ 를 사용하여 동중간섭을 하는 $\mathrm{Br}$ 을 제거하 였고 남은 $\mathrm{Br}$ 에 의한 간섭은 수학적 보정을 사용하여 정확한 셀레늄 화학종의 양을 정량할 수 있었다. 실험 에서 구한 값들은 생선시료들이 대개 $\mathrm{mg} / \mathrm{kg}$ 수준이거 나 그 이하이며 이 값들은 다른 문헌값들과 비슷한 수준이었다.

화학종 연구의 가장 큰 관건은 시료에서 화학종을 추출할 때에 화학종간의 전이가 일어나지 않아야 하 며 모두 추출되어야 하는 것이다. 아직 동위원소로 표 지된 표준물이 없으므로 이 부분에 대한 연구가 부족 하며 앞으로 동위원소 표지물을 합성하여 더 실험하 여야 추출에 대한 정확성을 입증할 수 있을 것으로 생각한다.

아직까지 국내에서는 셀레늄 총량에 관한 연구가 대부분이며 화학종에 관한 연구는 부족한 실정이다. 본 연구는 국내에서 처음으로 해산물에서의 셀레늄 화학종들의 정량분석을 하였다. 셀레늄의 화학종에 대 한 연구는 그 범위가 매우 넓다. 예를 들어, 셀레늄은 인체에서 다양한 화학종으로 존재하며 그 형태와 농 도에 따라 인체에 미치는 영향이 달라질 수 있으므로 더욱 다양한 환경, 식품, 생체 시료 등에서 셀레늄 화 학종에 관한 계속적인 연구가 필요하며 수행되어야 할 것이다.

\section{감사의 글}

본 연구는 한국연구재단의 일반연구(2010-0010880) 의 도움으로 이루어진 것으로 이에 감사드립니다.

\section{참고문헌}

1. C. D. Thompson, Assesment of requirements for $\mathrm{Se}$ and adequacy of Se status: a review. Eur. J. Clin. Nutr., 58, 391-402 (2004).

2. S. B. Goldhaber, Regulatory Toxicol. and Pharm., 38, 232-242 (2003).

3. L. V. Rapp, J. Lu, A. Holmgren and K. K. Khanna, Antioxid. Redox Signal., 9, 775-806 (2007).

4. U. Tinggi, Toxicol. Lett., 137, 103-110 (2003).

5. R. C. McKenzie Jr., T. S. Rafferty, and G. J. Beckett, 
Immunol. Today, 19, 342-345 (1998).

6. P. Leonhard, R. Pepelink, A. Prange, N. Yamad and T. Yamada, J. Anal. At. Spectrom., 17, 189-197 (2002).

7. D. Wallschlager and J. London, J. Anal. At. Spectrom., 19, 1119-1125 (2004).

8. P. C. Uden, Anal. Bioanal. Chem., 373, 422-431 (2002).

9. M. Navaro-Alarcon and C. Cabrea-Vique, A review. Sci. Redox Signal., 9, 775-806 (2008).

10. Y. J. Choi, J. Y. Kim, H. S. Lee, C. I. Kim, I. K. Hwang, H. K. Park and C. H. Oh, J. of Food Comp. and Anal., 22, 117-122 (2009).

11. Y. Miyazaki, H. Koyama, Y. Sasada, H. Satoh, M. Nojiri, and S. Suzuki, J. Nutr. Sci. Vitaminol., 50, 309319 (2004).

12. H. S. Douglas, V. C. Morris, J. H. Soares Jr. and O. A. Leavander, J. Nutr., 111, 2180-2187 (1981).

13. B. O. Gabrielsen and J. Opstvedt, J. Nutr., 110, 10961100 (1980).

14. T. E. Fox, E. G. H. M. Van den Heuvel, C. A. Atherton, J. R. Dainty, D. J. Lewis, N. J. Langford, H. M. Crews, J. B. Luten, P. Van Dael and S. J. FairweatherTait, Eur. H. Clin. Nutr., 58, 343-349 (2004).

15. M. Yoshida, M. Abe, K. Fukunaga and K. Kikuchi, Food Addit. Contam., 19, 990-995 (2002).

16. D. H. Vanesa, L. F. S. Maria and S. M. Alfredo, Anal. Chim. Acta, 538, 99-105 (2005).
17. T. Celine, R. Ann, D. T. Ludwig, S. Yves-Jacques and P. Luc, Food Chemistry, 130, 767-784 (2012).

18. P. Moreno, M. A. Quijano, A. M. Gutierrez, M. C. Perez-Conde and C. Camara, Anal. Chim. Acta, 524, 315-327 (2004).

19. L. H. Reyes, J. L. Mar, G. M. Rahman, B. Seybert, T. Fahrengolz and H. M. Kingston, Talanta, 78, 983-990 (2009).

20. M. A. Quijano, P. Moreno, A. M. Gutierrez, M. C. PerezCode and C. Camara, J. of Mass Spectrom., 35, 878884 (2000).

21. H. Jang, H. Min, J. Lee and Y. Pak, Anal. Sci. Tech., 26, 182-189 (2013).

22. D. Schaumloffel, K. Bierla and R. Lobinski, J. Anal. At. Spectrom., 22, 318-321 (2007).

23. K. G. Heumann, L. Rottmann and J. Vogl, J. Anal. At. Spectrom., 9, 1351-1362 (1994).

24. H. Cho, Y. Pak, J. of Kor. Chem. Soc., 55(3), 472-477 (2011).

25. N. Luque, S. Rubio and D. Perez-Bendito, Anal. Chim. Acta, 584, 181-188 (2007).

26. M. Dernovicsa and R. Lobinski, J. Anal. At. Spectrom., 23, 744-751 (2008).

27. Korea Food \& Drug Administration 위해 예방정책과, 유해물질 총서, 셀레늄, 2010. 12, Republic of Korea. 